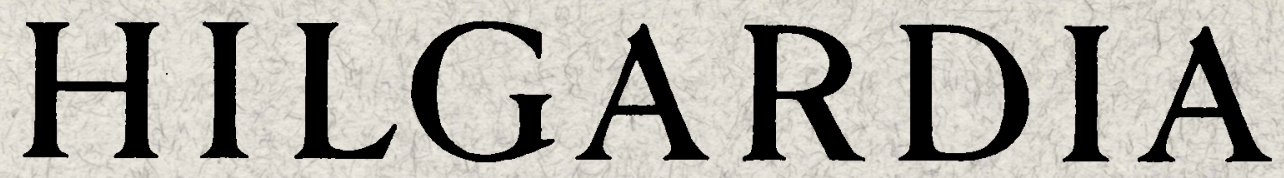

A Journal of Agricultural Science Published by the California Agricultural Experiment Station

\title{
SOME PHYSIOLOGICAL RESPONSES \\ IN TWO TOMATO VARIETIES \\ ASSOCIATED WITH LEVELS OF SOIL BULK DENSITY
}

\author{
WILLIAM J. FLOCKER \\ and \\ ROBERT C. MENARY
}

UNIVERSITY OF CALIFORNIA - BERKELEY, CALIFORNIA 


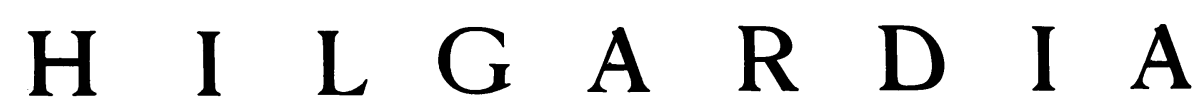

A Journal of Agricultural Science Published by

the California Agricultural Experiment Station

VoL. 30

JULY, 1960

No. 3

\title{
SOME PHYSIOLOGICAL RESPONSES IN TWO TOMATO VARIETIES ASSOCIATED WITH LEVELS OF SOIL BULK DENSITY ${ }^{1}$
}

\author{
WILLIAM J. FLOCKER ${ }^{2}$ and ROBERT C. MENARY ${ }^{3}$
}

\section{INTRODUCTION}

The movement of water and gases through soil is restricted by increases in the bulk density. Penetration of soil by roots is also restricted by high bulk densities as a result of increased mechanical resistance. Unfortunately, this phenomenon is unavoidable and is perhaps inseparably associated with undesirable soil moisture and soil aeration characteristics. The net effect of these interactions is a general reduction in plant vigor.

Since soil air spaces are markedly reduced by increasing bulk density, it is quite probable that lack of soil aeration may be an important factor in limiting plant growth. Bertrand and Kohnke $(1957)^{4}$ found that compaction of subsoil significantly slowed the diffusion of soil gases, which reduced the growth of corn plants. Improper composition of soil air in the root zone tends to induce slow-growing root systems (Lawton, 1946), inadequate nutrient (Danielson and Russell, 1957; Lawton, 1946 ; Loehwing, 1934), and water absorption (Hagan, 1950), and a delay in or failure of reproductive processes (Albert and Armstrong, 1931). Loehwing showed that aerated sunflowers and soybeans in sand and/or loam cultures absorbed greater amounts of calcium, phosphorus, and potassium than did unaerated controls. Total weight per plant of crude fiber, starch, total sugars, and nitrogen also increased. Lawton reported that nutrients absorbed by crops grown in nutrient solutions under restricted aeration were reduced in the following order of magnitude: $\mathrm{K}>\mathrm{Ca}>\mathrm{Mg}>\mathrm{N}>\mathrm{P}$. Results were similar when soil aeration was restricted by reducing soil porosity. The effect of compaction on calcium uptake may influence the incidence of blossom-end rot in tomatoes, for it is generally accepted that calcium deficiency may be a contributing factor in the prevalence of this physiological disorder (Martin, 1954; Nightingale et

\footnotetext{
${ }^{1}$ Received for publication March 11, 1959.

${ }^{2}$ Assistant Olericulturist, Vegetable Crops Department, Davis, California.

${ }^{3}$ Former graduate student, Vegetable Crops Department, Davis, California.

"See "Literature Cited" for citations, referred to in the text by author and date.
} 
al., 1931; Taylor and Smith, 1957). Certain varieties have been observed to show varying degrees of resistance or susceptibility to the disorder (Young, 1942); however, in this study, the effects of soil compaction on calcium uptake did not influence the incidence of blossom-end rot in tomatoes.

The effects of oxygen and carbon dioxide concentrations on tomato growth and absorption of nutrients have been investigated (Erickson, 1946; Hopkins et al., 1950; Vlamis and Davis, 1944). Hopkins et al. showed that 0.5 per cent oxygen in the gas around tomato roots stopped root growth. Erickson reported that root growth was reduced slightly by 9.1 per cent $\mathrm{CO}_{2}$, and drastically by 28.8 per cent. Hopkins et al. also showed that accumulation of macronutrients in plants parallels top growth in dependence upon oxygen supply to roots. Magnesium appears to remain relatively constant.

Veihmeyer and Hendrickson (1948) reported that relatively high subsoil densities prevent the entry of roots of sunflower, pine, grape, fig, and chaparral. They showed experimentally that root growth is a function of bulk density and that it varies with soil texture. Since roots were able to penetrate saturated noncompacted soil from which air had been expelled by heating, they concluded that the failure of root development in highly compacted soils is due to the small size of pores.

Literature to date does not adequately define the biological implications of a general soil condition called "compaction." There is still a great deal of uncertainty about the relative importance of the many soil factors that vary with compaction. Despite the difficulty of measuring all possible soil variables, this study was undertaken to investigate some growth responses and nutrient levels in two tomato varieties grown on a Yolo fine sandy loam at three different levels of soil bulk densities.

\section{MATERIAL AND METHODS}

\section{Greenhouse Methods}

Experiment 1. The $2 \times 3 \times 3$ split-plot factorial design consisted of six replications, each containing two varieties, three rates of calcium application, and three bulk densities. The two tomato varieties were Pearson and Sutton's Best of All. The former has shown resistance to blossom-end rot (Young, 1942), whereas the latter is generally considered susceptible. The soil used was Yolo fine sandy loam.

Experiment 2. The design was a $4 \times 3 \times 3$ split-plot factorial design with three replications. Each replicate contained four varieties, three calcium levels, and three bulk densities. Four synthetic "varieties" were created by grafting Pearson plants on Sutton's Best of All, vice versa, and each variety on its own rootstock. Since the Pearson variety exhibits some resistance to blossom-end rot, it was thought that grafting a susceptible variety on a resistant rootstock, and vice versa, might clarify any differences in the abilities of different rootstocks in withdrawing nutrients differentially from the soil. Yolo fine sandy loam was compressed to bulk densities of 1.1, 1.4, and 1.7. A solution of calcium nitrate and calcium ${ }^{45}$ chloride was mixed according to the isotopic dilution technique described by Kamen (1951). Since the ratio between these two forms of the same element was known, then according to the above-mentioned technique, they could be treated as a single 
source of applied calcium- $\mathrm{Ca}^{45}$. Proper aliquots of this precalculated solution were added to the soil to give a total single application rate of 0,30 , and $60 \mathrm{ppm}$. of calcium, and hereafter in this paper the applied calcium will be referred to as $\mathrm{Ca}^{45}$. The actual amounts of radioactive calcium included in the respective treatments were $0,0.13$, and $0.26 \mathrm{ppm}$. The different nitrate levels resulting from the differential calcium treatments were balanced with potassium nitrate.

Soil Treatment. Air-dry Yolo fine sandy loam was screened through a 2-mm. sieve. Enough distilled water plus the solution containing the $\mathrm{Ca}^{45}$ treatment was added to raise moisture content to 16 per cent (oven-dry basis). The soil was then thoroughly mixed and passed through a $4-\mathrm{mm}$. sieve. Soil was stored two weeks in sealed polyethylene bags so that the moisture in the soil could come to equilibrium. The weight of soil for each pot of a given density was calculated from the volume of the pot, the moisture content, and the bulk density required. To ensure a more even distribution of density, the amount of wet soil required for each pot was divided into four equal parts and (with a Carver hydraulic press) packed in the pot in successive layers to the desired volume. The surface of each layer was scarified with a fork to eliminate packing interfaces between layers. The final volume of soil was 2,750 ce.

Ten tomato seeds were planted per pot, in a V-shaped trench one-fourth inch in depth. The seeds were placed in the trench at equal spacings of about one-eighth inch. The trench was filled with soil and repacked with the fingers to its original level. During germination and thereafter, moisture was maintained as closely as possible to the original level of 16 per cent. This was approximated by weighing the individual pots at 3-day intervals during the first three weeks. Thereafter, plant leaf and soil symptoms were used as the criteria for adding water. Water was added in small increments of about 50 cc. as observation of plant and soil indicated the need. Some physical properties of the soil are given in tables 1 and 2 .

Germination counts were made daily for seven days from the time seedlings began to emerge. Average day of emergence was calculated according to the method of Harrington and Minges (1954). Plants were subsequently thinned to two per pot.

Six weeks after planting, one plant from each pot was grafted to give the combinations mentioned above. The experiment was so designed that scion material could be interchanged on pots that had received the same soil treatment.

Respective day and night temperatures were maintained at $75^{\circ} \mathrm{F}$. and $65^{\circ} \mathrm{F}$. A time lag in the heating and cooling systems caused variations of $\pm 10^{\circ} \mathrm{F}$.

\section{Chemical Methods}

Plant Tissue Analysis. Plant tissue was ground to pass through a 40 -mesh sieve. One-gram samples of this material were ashed, and the resultant ash was digested in $0.1 \mathrm{~N} \mathrm{HCl}$ and brought to a standard volume of $100 \mathrm{ml}$. Cation analysis on aliquots of this standard solution was performed with a line-operated Beckman DU Flame Spectrophotometer, equipped with a Photomultiplier unit (Brown et al., 1952; Fields et al., 1951). Total phos- 


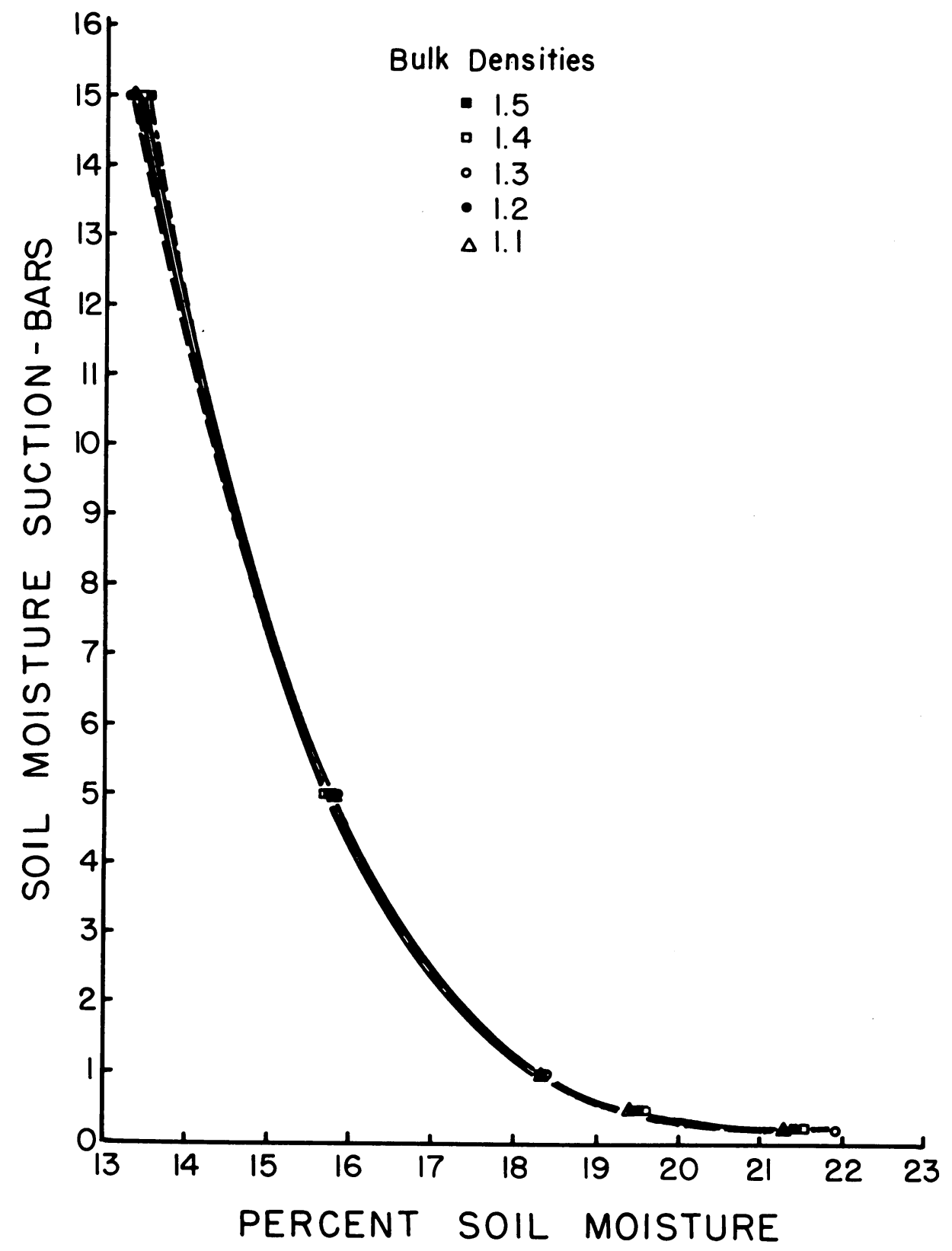

Fig. 1. Soil moisture desorption curves for Yolo fine sandy loam. 
phorus was determined colorimetrically after the method of Dickman and Bray (1940), total sugars after the method of Hassid (1936), and protein nitrogen after the method described by the A.O.A.C. (1955).

A 1-ml. aliquot of plant extract, previously described, was evaporated to dryness in a planchet for radioactivity determinations in an internal gasflow scintillation counter. The scaling unit was a Tracer Lab. S.C.-16 windowless flow counter with S.C.-51 auto scaler. Counting was done under a constant $2 \pi$ geometry.

Soil Analysis. Some of the physical and chemical properties of the soil used are given in table 2 . Water-soluble phosphate was analyzed by the method of Bingham (1949). Exchangeable cations on an ammonium acetate extract of the soil were determined with the Beckman DU Flame Spectrophotometer mentioned above. The $\mathrm{pH}$ of the soil was determined on a 1:1 soil paste. Physical measurements were made according to methods listed by Lambe (1951).

\section{Physical Methods}

At the completion of the experiment, soil cores were taken to determine any change in bulk density level during the experiment (table 1). The core sampler used is described by Richards (1954).

The distribution of soil moisture content was also determined on these pots at the conclusion of the experiment by sampling in 2-inch increments the entire depth of the can. Determination of the moisture content showed an extreme variation of 14.1 to 20.6 per cent. The greatest differential within a single pot was 6.6 per cent; the least was 1.1 per cent. Five moisture desorption curves were constructed for this soil, compressed to five different densities. A plot of the soil suction vs. percentage of soil moisture for these densities is shown in figure 1. From the desorption curves, the above soil moisture values correspond to soil suctions of about 10 bars and 1 bar.

Soil moisture suction, especially at high density levels caused by compaction, is difficult to control. Therefore, the greatest influence on the results may well be attributed to these large differences; in fact, they could be the dominating factors. While the results in the tables are reported as effects of bulk density levels, it must be realized that the effects associated with these levels play a more important role than soil density per se. Other contributing factors undoubtedly include soil aeration, mechanical impedance, and nutrient uptake.

Total fresh and dry weights of aerial portions were taken for each plant. Experiments 1 and 2 were harvested nine and nineteen weeks from seeding, respectively. Plant material from experiment 1 was lyophilized to prevent further metabolic activity after harvest. Material from experiment 2 was dried seventy-two hours at $70^{\circ} \mathrm{C}$. in a dehydrator.

\section{Statistical Methods}

The data from experiment 1 were analyzed as a $2 \times 3 \times 3$ split-plot factorial and data from experiment 2 as a $4 \times 3 \times 3$ split-plot factorial, according to the methods of Snedecor (1956). Duncan's multiple-range test was applied to significant "F" values, as suggested by Alder and Roessler (1958). 


\section{RESULTS AND DISCUSSION \\ Experiment 1}

Average Day of Emergence. Average day of emergence has been used to indicate rate of emergence (Harrington and Minges, 1954). It is obtained by summing, for each day, the product of percentage germinated multiplied by number of days from planting, and dividing this sum by the total percentage germinated. The formula is:

$$
\text { Av. day emer. }=\frac{\text { No. of days } \times \% \text { germ. }+ \text { no. of days } \times \% \text { germ. }+\cdots}{\text { Total } \% \text { germ. }}
$$

The results are given in table 3 . The germination percentage of the seed used in this experiment, as determined by the blotter test, was 99 per cent.

The average day of emergence was significantly increased at a bulk density level of 1.7 above that resulting from density levels of 1.4 and 1.1. There was no significant difference at the 1 per cent level in emergence rates between densities 1.1 and 1.4. Plants grown in a soil density of 1.7 required an average of about one day longer to emerge (table 3 ).

In the moisture range tested, the percentage of air space at a bulk density of 1.7 was about 7.2 (table 1 ). From these data it appears that for this soil a total soil air space of less than about 7 per cent retards the rate of emergence of tomatoes.

Tomato variety and rate of application of $\mathrm{Ca}^{45}$ had no significant effect on rate of emergence.

Growth and Yield. In this investigation, growth is reported in terms of plant height. It was defined as the distance from soil surface to shoot apex. Total height of each plant was measured weekly for nine weeks after seeding. The results (table 4 ) show a significant (1 per cent level) decrease in plant growth at bulk density 1.7 as compared with that at 1.4 and 1.1. Decreasing soil air space from about 40 per cent to 7 per cent reduced height 50 per cent (fig. 2).

The effects of levels of soil bulk density on the dry-weight production of tomato shoots are also given in table 4 . Dry-weight production was about 13 per cent higher at soil density 1.1 than at soil densities 1.7 and $1.4 . \mathrm{Ca}^{45}$ fertilizer had no effect on dry-weight production of tomato shoots.

The ratio of fresh weight to dry weight was not significantly different at the 5 per cent level.

Flower-Bud Numbers. The numbers of flower buds were counted and recorded nine weeks after seeding. A highly significant difference in numbers of buds on tomatoes was found between soil density levels of 1.1, 1.4, and 1.7. These data are given in table 4 . The numbers of flower buds from plants grown on soil densities of 1.4 and 1.1 were, respectively, about three and four times as great as those grown on density 1.7.

Sugars, Protein, and Anthocyanin. Plants grown in pots with high soil densities developed very marked accumulations of anthocyanin pigment. Plants grown in soil at density 1.7 developed a general purpling of veins and laminae on the ventral side of all leaves. Veins on the dorsal side showed a deep purpling, while the laminae showed dense interveinal spotting. Stems were entirely purple. Plants grown at bulk density 1.4 showed some vein 


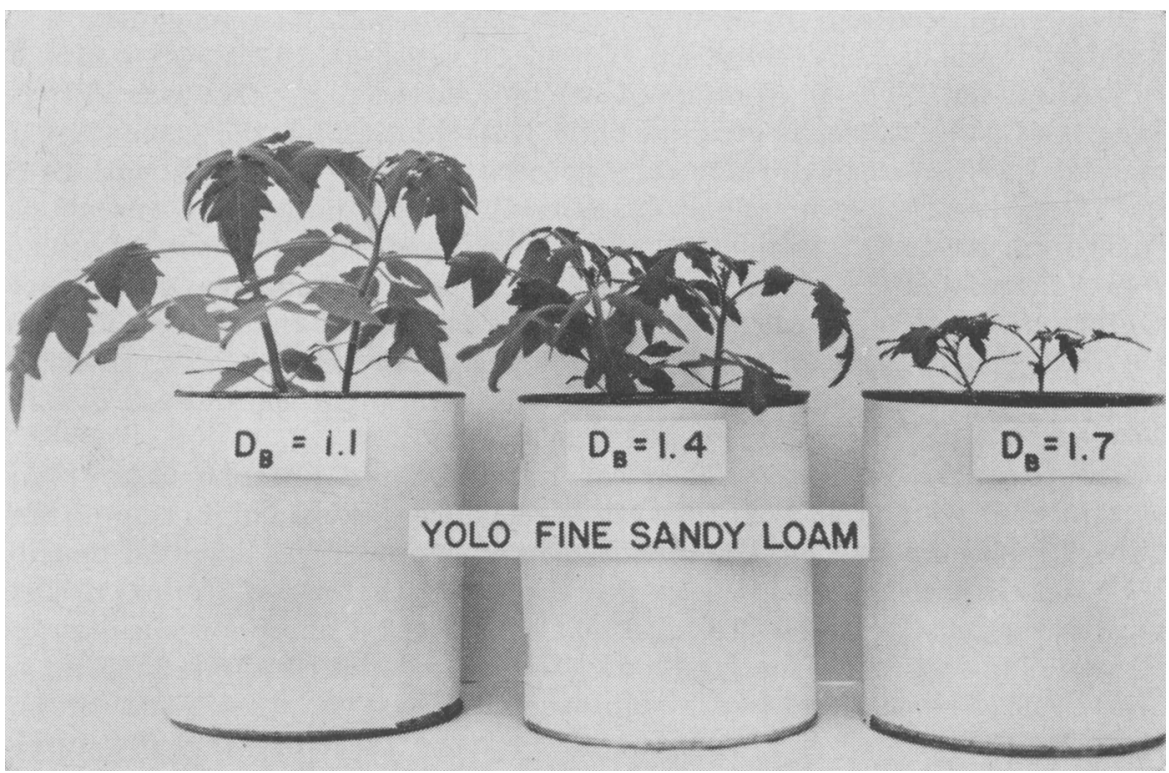

Fig. 2. Effect of levels of soil bulk density of Yolo fine sandy loam on the height of tomato plants six weeks after seeding.

purpling on the ventral side of leaves, with occasional small patches on the laminae. There was a slight marginal spotting on the dorsal side of the laminae. Plants grown on soil at bulk density 1.1 showed no signs of purpling.

Chemical analysis of lyophilized tissue from aerial portions of plants showed significant differences at the 5 per cent level between densities 1.1 and 1.7 in protein content (table 5 ).

Total protein per plant increased slightly in plants from soils of high density, even though dry weight was lowest at this density.

Total sugars, expressed as mg. per gm. dry weight, were significantly (1. per cent level) reduced in plants grown in bulk density 1.7 as compared with 1.4 (table 6).

Nutrient Absorption: Total Calcium. Calcium in plant tissue, expressed as percentage of dry weight, showed a highly significant increase from soil applications of 30 and $60 \mathrm{ppm}$. of $\mathrm{Ca}^{45}$ (table 7 ). Total calcium uptake per plant was greatly increased through increased soil applications. However, the calcium content of plant tissue, expressed either as percentage of dry weight or as total uptake per plant, was not significantly affected by changes in soil density.

Total Magnesium. Means for magnesium content (percentage of dry weight) and total uptake per plant (mg/plant) are also given in table 7 . Magnesium content of plants was significantly greater when 30 and $60 \mathrm{ppm}$. $\mathrm{Ca}^{45}$ were applied than when no $\mathrm{Ca}^{45}$ was applied. Both percentage content and total uptake of magnesium were highest when $\mathrm{Ca}^{45}$ was applied at 60 ppm. 
Magnesium content of tomato shoots did not vary significantly with different levels of soil density.

Applied $\mathbf{C a}^{45}$. The percentage of calcium in the plant that was derived from the $\mathrm{Ca}^{45}$ fertilizer is given in table 8. At density 1.1, the percentage of applied $\mathrm{Ca}^{45}$ absorbed did not vary greatly with increased applications of $\mathrm{Ca}^{45}$ fertilizer. However, at soil densities of 1.4 , the percentage of $\mathrm{Ca}^{45} \mathrm{de}-$ rived from the fertilizer almost doubled when application rate was doubled.

Soil density levels appear to have had very little influence on the percentage of calcium absorbed when $\mathrm{Ca}^{45}$ was applied at the rate of $30 \mathrm{ppm}$. (table 8), but significantly affected that percentage when $\mathrm{Ca}^{45}$ application rate was $60 \mathrm{ppm}$. The interaction between $\mathrm{Ca}^{45}$ application and soil density was highly significant (1 per cent level).

Phosphorus. Results of the chemical analysis of total phosphorus per plant are summarized in table 9 . An analysis of variance yielded a highly significant $\mathrm{Ca}^{45} \times$ Density interaction. Phosphorus content (ppm.) was lowest at density 1.7 when $\mathrm{Ca}^{45}$ was not applied, or was applied at the rate of $30 \mathrm{ppm}$. Plants grown at a density level of 1.1 with no $\mathrm{Ca}^{45}$ showed a phosphorus content of about $200 \mathrm{ppm}$. greater than those with 30 and $60 \mathrm{ppm}$. of applied $\mathrm{Ca}^{45}$. At a high density level, there was a significant decrease in phosphorus content (table 9) and growth (table 4). It would appear, therefore, that the supply of phosphorus under these conditions is a limiting factor with respect to plant growth.

\section{Experiment 2}

Growth and Yield. Dry-weight determinations on aerial portions above the graft yielded significant differences between varieties (table 10). Sutton's Best of All/Sutton's Best of All produced significantly (1 per cent level) more dry matter than did Pearson/Pearson, Pearson/Sutton's Best of All, and Sutton's Best of All/Pearson. Sutton's Best of All seemed slightly retarded by being grafted on Pearson rootstocks.

The analysis of variance for dry-weight data gave a highly significant (1 per cent level) $\mathrm{Ca}^{45} \times$ Density interaction (table 11). At soil density levels 1.1 and 1.4, dry-weight production of tomato shoots showed a steady increase with increasing $\mathrm{Ca}^{45}$ applications. At soil density 1.4, dry-weight yield generally exceeded that at 1.1 by about 15 per cent. At density 1.7, dry weight of tomato shoots increased as $\mathrm{Ca}^{45}$ fertilizer was increased from no fertilizer up to $30 \mathrm{ppm}$., but at $60 \mathrm{ppm}$. it decreased appreciably, concurrently with a sharp decrease in phosphorus uptake (table 20). Dry-weight production was greatest at a soil density of 1.4 and reached a maximum at this density with a $\mathrm{Ca}^{45}$ application rate of $60 \mathrm{ppm}$.

Root Distribution. Nineteen weeks after seeds were planted, the cans were cut open to observe root distribution. At soil bulk density level of 1.1, primary and secondary root development had become extensive throughout the 6 -inch pot. At soil density 1.4, lateral root development was concentrated in the 2-to-4-inch depth, with sparse distribution in the rest of the pot. Taproots were able to penetrate the latter zone, but were somewhat knotted and twisted. At bulk density level 1.7, root distribution was con- 
centrated in the upper inch of soil. Although lateral root development in this zone was extensive, there was no obvious taproot.

Fruit Production. Number and fresh weight of fruits were recorded at harvest time. The difference between varieties in fruit number and fresh-fruit weight per plant was highly significant (table 12). Sutton's Best of All scions set about twice as much fruit as Pearson. Pearson/Pearson and Pearson/Sutton's Best of All were not significantly different, nor were Sutton's Best of All/Pearson and Sutton's Best of All/Sutton's Best of All. The analysis of variance for fruit number indicated a significant $\mathrm{Ca}^{45} \times$ Density interaction. Results followed the trend indicated for dry-weight production. Fruit weight on Sutton's Best of All or Pearson scions was not significantly influenced by rootstock; however, the difference between varieties was highly significant (table 12). The effect of different levels of soil density on fruit weight per plant is presented in table 13. Mean fruit weight per plant was significantly (1 per cent level) less at soil density 1.7 than at 1.1 or 1.4 . There was no significant difference between densities 1.1 and 1.4 in fresh-fruit weight per plant.

Nutrient Absorption: Calcium. The percentage of calcium in tomato shoots varied considerably with different soil bulk density levels. Mean values and significant differences of calcium and magnesium contents are summarized in table 14. Percentage of total calcium in tomato shoots was highly significantly less at soil density 1.1 than at soil densities of 1.4 and 1.7. Total calcium expressed as mg. per plant shows that uptake was lowest in plants grown at the 1.7 density level, slightly greater at bulk density 1.1, and highest at density 1.4. Total uptake was about 30 per cent greater at soil bulk density level 1.4 than at 1.7 or 1.1 .

Mean values (ppm. dry weight) of $\mathrm{Ca}^{45}$ derived from the applied $\mathrm{Ca}^{45}$ fertilizer in tomato shoots grown at soil densities 1.1, 1.4, and 1.7 are also given in table 14. The $\mathrm{Ca}^{45}$ content of shoots was significantly less at soil densities 1.1 and 1.7 than at soil density 1.4. When $\mathrm{Ca}^{45}$ is expressed as mg. per plant, uptake was lowest at soil density 1.7, slightly greater at density 1.1, and about 47 per cent greater at density 1.4. Doubling the soil application of $\mathrm{Ca}^{45}$ approximately doubled the $\mathrm{Ca}^{45}$ (ppm. dry weight) content in the tomato shoots (table 15). This same trend is noted when $\mathrm{Ca}^{45}$ is expressed as mg. $\mathrm{Ca}^{45}$ per plant. However, the doubled rate of $\mathrm{Ca}^{45}$ fertilizer had no significant effect on total calcium content of tomato shoots when expressed as percentage of dry weight or mg. per plant (table 16).

The percentage of calcium in plant tissue that was derived from the applied $\mathrm{Ca}^{45}$ fertilizer at different densities is given in table 17 . The soil density level of 1.4 seemed to be optimum for absorption of $\mathrm{Ca}^{45}$ fertilizer by tomatoes grown on Yolo soil. At this density, 51.7 per cent of the calcium in the shoot was derived from the fertilizer. This percentage was reduced 6 per cent at soil density 1.7.

Percentage of total calcium and magnesium in shoot tissue of the different varieties is given in table 18. At the 1 per cent level of significance, percentage of calcium was significantly higher in Sutton's Best of All/Sutton's Best of All than in Pearson/Pearson and Pearson/Sutton's Best of All. When calcium is expressed as mg. per plant, total uptake is higher for Sutton's Best 
of All than for Pearson. The calcium uptake of Sutton's Best of All on Pearson rootstocks is less by $32 \mathrm{mg}$. per plant than for Sutton's Best of All on its own rootstock. Uptake of calcium (mg. per plant) by Pearson, on the other hand, was slightly increased by the Sutton's Best of All rootstock. These data show that the root systems of the two tomato varieties differ in their ability to absorb calcium from the soil.

Magnesium. A summary of mean values for percentage of magnesium in plant tissue is given in table 18. Results show a highly significant difference ( 1 per cent level) between the percentage of magnesium in Pearson/Pearson and Sutton's Best of All/Sutton's Best of All. Sutton's Best of All shoots contained about 25 per cent more magnesium (percentage of dry weight) than did Pearson. When magnesium is expressed as mg. per plant, Sutton's Best of All absorbed 42 per cent more of the element than did Pearson. Sutton's Best of All rootstocks increased the magnesium content of the Pearson scion by about 7 per cent, whereas Pearson rootstocks decreased the magnesium content of Sutton's Best of All scions by about 10 per cent.

Table 14 shows the effect of level of soil density on the percentage of magnesium in plant tissue and the total amount absorbed by tomato shoots. The percentage of magnesium is significantly greater in plants grown in soil at bulk densities of 1.7 and 1.4 than in plants grown at density 1.1 Total uptake per plant at the three densities shows the same trend.

Phosphorus. Variable phosphorus contents of tomato shoots were associated with variety. Results are summarized in table 19. At the 5 per cent level of significance, the phosphorus content of Sutton's Best of All/Sutton's Best of All and Sutton's Best of All/Pearson differed from the phosphorus content of Pearson/Pearson and Pearson/Sutton's Best of All. At the 1 per cent level, phosphorus content of Sutton's Best of All/Pearson was significantly lower than that of Pearson/Sutton's Best of All. When phosphorus is expressed as mg. per plant, uptake shows no appreciable differences between varieties. Each variety can apparently absorb phosphorus with the same facility.

The analysis of variance for phosphorus content yielded a highly significant $\mathrm{Ca}^{45} \times$ Density interaction (table 20). This same interaction was apparent in experiment 1 (table 9). A decrease in ppm. of phosphorus in plant tissue and total uptake per plant by tomato shoots was apparent as soil density increased when no calcium was applied. Phosphorus absorption (mg. per plant) was maximum at soil density 1.4 and a $\mathrm{Ca}^{45}$ application rate of $60 \mathrm{ppm}$. At soil densities 1.4 and 1.7, phosphorus absorption and production of dry weight by tomato shoots followed identical trends (tables 20 and 9 ).

\section{SUMMARY}

It is generally accepted that high soil densities restrict plant growth (Bertrand and Kohnke, 1957; Flocker et al., 1959), but the physiological reasons are not entirely known. Some quantitative data are given in an endeavor to define soil compaction in terms of plant composition and growth.

Increased time of emergence was the first observable symptom of decreased plant vigor in tomato seedlings grown at high soil densities. Average day of emergence at soil density 1.7 was one day longer than at density 1.4 . The 
average air space at this level of density was 7 per cent. The data indicate that soil air spaces below 7 per cent were inhibitory to rate of emergence of tomato seedlings.

Height, bud count, fruit number, fruit weight, and dry weight of tomato plants varied with changes in the densities of the soil medium. Plant height nine weeks after planting was 50 per cent less at soil density 1.1 than at 1.7. Bud counts at the same stage of growth showed that plants grown at densities of 1.4 and 1.1 were respectively three and four times greater than the count at density 1.7. Nineteen weeks after planting day, fruit number and freshfruit weight still gave the same trend as indicated above for plant height. Maximum root development was restricted to the top inch of the soil for those plants growing in pots compacted to a density of 1.7. A soil density of 1.4 was sufficient to restrict lateral root development in the 4 -to-6-inch soil layer.

Anthocyanin accumulation occurred in the leaves and stems of tomatoes grown at soil densities 1.7 and 1.4. This phenomenon became less apparent ten weeks after planting. Sugar and protein analyses of the young leaves and stems show that high protein and low sugar content are characteristic of tomatoes grown on compacted soils.

At soil density level of 1.1 , absorption of $\mathrm{Ca}^{45}$ fertilizer by young tomato plants (nine weeks) was not increased by increasing soil applications from 30 to $60 \mathrm{ppm}$.

Fertilizer applications of 30 and $60 \mathrm{ppm} . \mathrm{Ca}^{45}$ significantly increased total calcium per shoot nine weeks after planting. This effect was not apparent nineteen weeks after planting.

Maximum calcium absorption (mg/plant) and percentage of $\mathrm{Ca}^{45}$ derived from applied $\mathrm{Ca}^{45}$ fertilizer occurred at density 1.4. Doubling the application rate of $\mathrm{Ca}^{45}$ fertilizer from 30 to $60 \mathrm{ppm}$. generally doubled the percentage of $\mathrm{Ca}^{45}$ that was absorbed by the plant.

$\mathrm{Ca}^{45}$ fertilizer applications of 30 and $60 \mathrm{ppm}$. decreased phosphorus absorption (ppm.) by tomatoes grown at densities 1.1 and 1.4, respectively. Sixty ppm. of $\mathrm{Ca}^{45}$ applied to the soil at density 1.7 reduced the total amount of phosphorus absorbed by the plant. Lack of phosphorus absorption was probably a factor contributing to the sharp decrease in dry weight and fruit number at that soil density.

$\mathrm{Ca}^{45}$ fertilizer applied at 30 and $60 \mathrm{ppm}$. increased magnesium uptake of young tomatoes about 100 per cent above that where no $\mathrm{Ca}^{45}$ was applied to the soil. Chemical analysis of tomato shoots nineteen weeks after planting showed that the effects produced by increasing the level of soil density constituted a more important factor in determining magnesium uptake than the rate of $\mathrm{Ca}^{45}$ fertilizer application. This lack of absorption of magnesium at soil density 1.7 was probably due to the inadequate distribution of roots throughout the depth of soil. The nine-week period was apparently not long enough for this root condition to show its effect on the nutrient status of the plant.

Some varietal characteristics were noted during this investigation. Tomato variety Sutton's Best of All initiated 100 per cent more flower buds than did variety Pearson after nine weeks' growth. After nineteen weeks' growth, 
Sutton's Best of All outyielded Pearson, in number and weight of fruit, by about 100 per cent. Total dry weight and moisture content of shoots were about 16-20 per cent higher for Sutton's Best of All than for Pearson. Sutton's Best of All tissue contained about 1,800 ppm. (dry weight) more calcium than did Pearson tissue. Total uptake of calcium by Sutton's Best of All shoots exceeded that of Pearson shoots by about $80 \mathrm{mg}$. per plant.

Although the percentage of phosphorus in plant tissue was highest for variety Pearson, total uptake was the same for each variety. Apparently, each variety has about the same ability to absorb phosphorus from the soil. Effects of increased soil density decreased phosphorus absorption by the tomato plant.

Magnesium followed the same trend as calcium. Variety Sutton's Best of All had about 2,000 ppm. (dry weight) more magnesium than did Pearson. Total uptake of magnesium by Sutton's Best of All exceeded that of Pearson by about $90 \mathrm{mg}$. per plant. The rootstocks of Sutton's Best of All tended to increase the magnesium and calcium content of Pearson scions. Pearson rootstocks had the opposite effect on Sutton's Best of All scions. 
EXPERIMENT 1

TABLE 1

SOME PHYSICAL PROPERTIES OF YOLO FINE SANDY LOAM

\begin{tabular}{|c|c|c|c|c|c|c|c|}
\hline \multicolumn{4}{|c|}{ At time of seeding } & \multicolumn{4}{|c|}{ At time of final harvest } \\
\hline \multirow{2}{*}{$\begin{array}{c}\text { Density } \\
\mathrm{gm} / \mathrm{cc}\end{array}$} & \multirow{2}{*}{$\begin{array}{l}\text { Porosity* } \\
\text { (per cent) }\end{array}$} & \multicolumn{2}{|c|}{ Air space* } & \multirow{2}{*}{$\begin{array}{l}\text { Density } \\
(\mathrm{gm} / \mathrm{cc})\end{array}$} & \multirow{2}{*}{$\begin{array}{l}\text { Porosity* } \\
\text { (per cent) }\end{array}$} & \multicolumn{2}{|c|}{ Air space* } \\
\hline & & $\underset{\text { (per cent) }}{\text { M.E. }}$ & $\begin{array}{c}\text { P.W.P. } \\
\text { (per cent) }\end{array}$ & & & $\begin{array}{c}\text { M.E. } \\
\text { (per cent) }\end{array}$ & $\underset{(\text { per cent) }}{\text { P.W.P. }}$ \\
\hline 1.1 & 59.3 & 40.0 & 49.7 & 1.3 & 53.3 & 31.2 & 42.4 \\
\hline 1.4 & 48.2 & 23.6 & 36.0 & 1.4 & 48.2 & 23.6 & 36.0 \\
\hline 1.7 & 37.0 & 7.2 & 22.3 & 1.7 & 37.0 & 7.2 & 22.3 \\
\hline
\end{tabular}

* Calculated values.

M.E. = moisture equivalent.

P.W.P. = permanent wilting percentage.

TABLE 2

SOME PHYSICAL AND CHEMICAL PROPERTIES OF YOLO FINE SANDY LOAM

\begin{tabular}{|c|c|c|c|c|c|c|}
\hline \multicolumn{7}{|c|}{ Chemical } \\
\hline \multirow{2}{*}{$\begin{array}{c}\mathrm{PO}_{4} \\
(\mathrm{ppm} .)\end{array}$} & \multicolumn{5}{|c|}{ Exchangeable cations (ppm.) } & \multirow{2}{*}{$\mathrm{pH}$} \\
\hline & $\mathbf{K}$ & $\mathrm{Na}$ & $\mathrm{Ca}$ & $\mathbf{M g}$ & Mn & \\
\hline 2.5 & 154 & 51 & 1,100 & 868 & 33.6 & 7.3 \\
\hline \multicolumn{7}{|c|}{ Physical } \\
\hline \multicolumn{3}{|c|}{ Per cent } & \multirow{2}{*}{$\underset{\text { (per cent) }}{\text { Moisture }}$} & \multirow{2}{*}{$\begin{array}{l}\text { Lower } \\
\text { plastic } \\
\text { limit } \\
\text { (per cent) }\end{array}$} & \multirow{2}{*}{$\begin{array}{l}\text { Upper } \\
\text { plastic } \\
\text { limit } \\
\text { (per cent) }\end{array}$} & \multirow{2}{*}{$\begin{array}{l}\text { Optimum } \\
\text { moisture for } \\
\text { compaction* } \\
\text { (per cent) }\end{array}$} \\
\hline Sand & Silt & Clay & & & & \\
\hline 49.0 & 32.1 & 18.9 & 20.5 & 21.0 & 31.5 & 24.5 \\
\hline
\end{tabular}

* Modified Proctor test.

TABLE 3

AVERAGE DAY OF EMERGENCE OF TOMATOES AS IN-

FLUENCED BY LEVELS OF SOIL BULK DENSITY OF YOLO FINE SANDY LOAM

\begin{tabular}{l|ccc}
\hline \hline Density $(\mathrm{gm} / \mathrm{cc}) \ldots \ldots \ldots \ldots \ldots \ldots \ldots$ & 1.4 & 1.1 & 1.7 \\
\hline Means (days) $\ldots \ldots \ldots \ldots \ldots \ldots \ldots \ldots$ & 9.3 & 9.6 & 10.3 \\
\cline { 2 - 3 } & & & $\star \star$ \\
\hline
\end{tabular}

Significant at the 1 per cent level.

Those numbers not connected by a horizontal line are significantly different. 
TABLE 4

GROWTH AND FLOWER BUDS ON NINE-WEEK-OLD TOMATO PLANTS AS INFLUENCED BY LEVELS OF SOIL BULK DENSITY OF YOLO FINE SANDY LOAM

\begin{tabular}{|c|c|c|c|}
\hline \multirow{2}{*}{$\begin{array}{l}\text { Density } \\
(\mathrm{gm} / \mathrm{cc})\end{array}$} & \multicolumn{3}{|c|}{ Means/plant } \\
\hline & $\begin{array}{c}\text { Height } \\
\text { (cm.) }\end{array}$ & $\begin{array}{c}\text { Dry-weight } \\
\text { yield } \\
\text { (gms.) }\end{array}$ & $\begin{array}{l}\text { Flower-bud } \\
\text { numbers }\end{array}$ \\
\hline 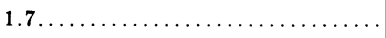 & 16.8 & 6.7 & 9 \\
\hline $1.4 \ldots \ldots \ldots \ldots \ldots \ldots \ldots \ldots \ldots$ & 29.7 & 6.7 & 29 \\
\hline $1.1 \ldots \ldots \ldots \ldots \ldots \ldots \ldots \ldots \ldots \ldots \ldots$ & $\begin{array}{r}31.7 \\
\star \star\end{array}$ & $\begin{array}{r}7.5 \\
\star \star\end{array}$ & 32 \\
\hline
\end{tabular}

Significant at the 1 per cent level.

Those numbers not connected by a vertical line are significantly different.

TABLE 5

EFFECT OF LEVELS OF SOIL BULK DENSITIES OF YOLO FINE SANDY LOAM ON THE PROTEIN CONTENT OF NINE-WEEK-OLD TOMATO SHOOTS

\begin{tabular}{|c|c|c|c|}
\hline Density $(\mathrm{gm} / \mathrm{cc}) \ldots \ldots \ldots \ldots \ldots \ldots$ & 1.1 & 1.4 & 1.7 \\
\hline Means (per cent D.W.). & 1.7 & 1.9 & 2.1 \\
\hline (mg/plant).. & 133.0 & $\overline{128.0}$ & $\overline{139.6}^{\star}$ \\
\hline
\end{tabular}

$\star$ Significant at the 5 per cent level.
D. W. $=$ dry weight.

TABLE 6

SUGAR CONTENT OF NINE-WEEK-OLD TOMATO SHOOTS AS INFLUENCED BY LEVELS OF SOIL BULK DENSITY OF YOLO FINE SANDY LOAM

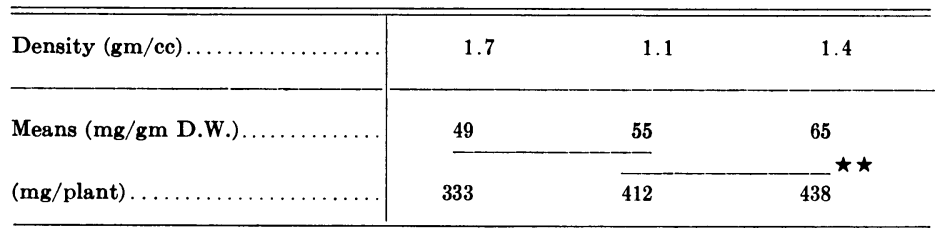

Significant at the 1 per cent level. 
TABLE 7

CALCIUM AND MAGNESIUM CONTENT OF NINE-WEEK-OLD TOMATO SHOOTS AS INFLUENCED BY APPLICATIONS OF Ca ${ }^{45}$ FERTILIZER

\begin{tabular}{|c|c|c|c|c|}
\hline \multirow{3}{*}{$\mathrm{Ca}^{45}$ applied (ppm.) } & \multicolumn{4}{|c|}{ Means/plant } \\
\hline & \multicolumn{2}{|c|}{ Total calcium } & \multicolumn{2}{|c|}{ Total magnesium } \\
\hline & Per cent D.W. & $\mathrm{mg} /$ plant & Per cent D.W. & mg/plant \\
\hline $30 \ldots$ & 1.7 & 120 & 2.2 & 251 \\
\hline $60 \ldots \ldots \ldots \ldots \ldots$ & 1.8 & 125 & 2.2 & 284 \\
\hline & $\star \star$ & $\star \star$ & $\star \star$ & $\star \star$ \\
\hline
\end{tabular}

Significant at the 1 per cent level.

TABLE 8

PERCENTAGE OF $\mathrm{Ca}^{45}$ IN NINE-WEEK-OLD TOMATO PLANTS DERIVED FROM APPLIED $\mathrm{Ca}^{45}$ FERTILIZER

\begin{tabular}{c|c|c|c}
\hline \multirow{2}{*}{$C^{*}$} & \multicolumn{3}{|c}{ Density } \\
\cline { 2 - 4 } & 1.1 & 1.4 & 1.7 \\
\hline & Per cent & Per cent & Per cent \\
\hline $30 \ldots \ldots \ldots \ldots \ldots \ldots \ldots \ldots \ldots \ldots \ldots \ldots$ & 4.03 & 3.87 & 4.19 \\
$60 \ldots \ldots \ldots \ldots \ldots \ldots \ldots \ldots \ldots \ldots \ldots \ldots \ldots$ & 4.57 & 7.50 & 6.19 \\
\hline
\end{tabular}

Interaction $\left(\mathrm{Ca}^{45} \times\right.$ Density). Significant at the 1 per cent level.

TABLE 9

PHOSPHORUS CONTENT OF NINE-WEEK-OLD TOMATO SHOOTS AS INFLUENCED BY LEVELS OF SOIL BULK DENSITY AND Ca ${ }^{45}$ APPLICATION TO YOLO FINE SANDY LOAM

\begin{tabular}{|c|c|c|c|c|c|c|}
\hline \multirow{3}{*}{$\begin{array}{c}\mathrm{Ca}^{45} \\
\text { applied } \\
\text { (ppm.) }\end{array}$} & \multicolumn{6}{|c|}{ Density } \\
\hline & \multicolumn{2}{|c|}{1.1} & \multicolumn{2}{|c|}{1.4} & \multicolumn{2}{|c|}{1.7} \\
\hline & ppm. & $\mathrm{mg} /$ plant & ppm. & $\mathrm{mg} /$ plant & ppm. & $\mathrm{mg} /$ plant \\
\hline 0. & 1,540 & 12 & 1,460 & 10 & 1,310 & 9 \\
\hline 30. & 1,380 & 10 & 1,360 & 10 & 1,320 & 11 \\
\hline 60. & 1,350 & 10 & 1,370 & 9 & 1,410 & 9 \\
\hline
\end{tabular}

Interaction $\left(\mathrm{Ca}^{45} \times\right.$ Density). Significant at the 1 per cent level. 


\section{EXPERIMENT 2}

TABLE 10

DRY WEIGHTS OF TOMATO SHOOTS NINETEEN WEEKS AFTER SEEDING

\begin{tabular}{l|cccc}
\hline \hline Variety............... & P/SBA & P/P & SBA/P & SBA/SBA \\
\hline Means (gm/plant) ........ & 18.9 & 19.0 & 21.2 & 22.3 \\
& & & -1
\end{tabular}

$\star \star$ Significant at the 1 per cent level.

TABLE 11

$\mathrm{Ca}^{45} \times$ DENSITY INTERACTION OF ANALYSIS OF

VARIANCE FOR DRY-WEIGHT YIELD OF

TOMATO SHOOTS

\begin{tabular}{|c|c|c|c|}
\hline \multirow{3}{*}{$\begin{array}{c}\mathrm{Ca}^{45} \text { applied } \\
\quad(\mathrm{ppm} .)\end{array}$} & \multicolumn{3}{|c|}{ Density } \\
\hline & 1.1 & 1.4 & 1.7 \\
\hline & gm. D.W. & gm. D.W. & gm. D.W. \\
\hline 0. & 17.5 & 21.0 & 18.6 \\
\hline $30 \ldots$ & 20.8 & 23.1 & 20.9 \\
\hline $60 \ldots$ & 22.8 & 25.7 & 12.7 \\
\hline
\end{tabular}

Interaction $\left(\mathrm{Ca}^{45} \times\right.$ Density). Significant at the 1 per cent level.

TABLE 12

NUMBER AND FRESH WEIGHT OF TOMATO

FRUITS PER PLANT NINETEEN WEEKS

AFTER SEEDING

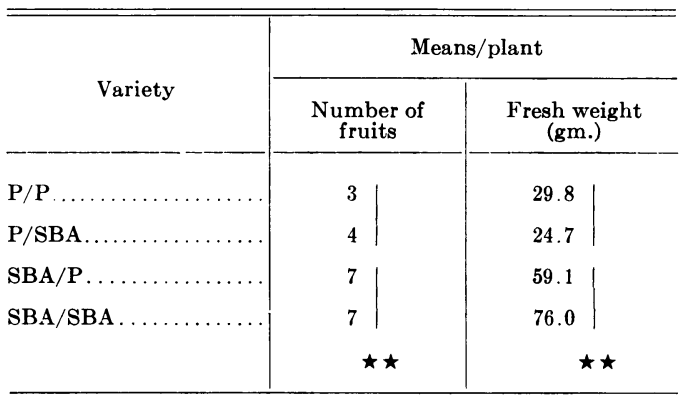

$\star \star$ Significant at the 1 per cent level. 
TABLE 13

FRESH-FRUIT WEIGHT PER PLANT AS INFLUENCED BY

LEVELS OF SOIL BULK DENSITY OF

YOLO FINE SANDY LOAM

\begin{tabular}{l|ccc}
\hline \hline Density $(\mathrm{gm} / \mathrm{cc}) \ldots \ldots \ldots \ldots \ldots \ldots \ldots$ & 1.7 & 1.1 & 1.4 \\
\hline Means (gm/plant) $\ldots \ldots \ldots \ldots \ldots \ldots$ & 30.5 & 53.3 & 58.3 \\
& & &
\end{tabular}$\star$

$\star \star$ Significant at the 1 per cent level.

TABLE 14

CALCIUM AND MAGNESIUM CONTENT IN TOMATO SHOOTS AS INFLUENCED BY LEVELS OF SOIL BULK DENSITY OF YOLO FINE SANDY LOAM

\begin{tabular}{|c|c|c|c|c|c|c|}
\hline \multirow{3}{*}{$\begin{array}{l}\text { Density } \\
(\mathrm{gm} / \mathrm{cc})\end{array}$} & \multicolumn{6}{|c|}{ Means } \\
\hline & \multicolumn{2}{|c|}{ Total calcium absorbed } & \multicolumn{2}{|c|}{$\begin{array}{l}\mathrm{Ca}^{45} \text { absorbed from } \\
\text { applied } \mathrm{Ca}^{45} \text { fertilizer }\end{array}$} & \multicolumn{2}{|c|}{ Magnesium content } \\
\hline & Per cent D.W. & $\mathrm{mg} /$ plant & ppm. D.W. & $\mathrm{mg} /$ plant & Per cent D.W. & $\mathrm{mg} /$ plant \\
\hline 1.1 & 1.08 & 221 & 23.4 & 0.48 & 0.92 & 187 \\
\hline 1.7 & 1.22 & 213 & 24.2 & 0.42 & 1.22 & 212 \\
\hline \multirow[t]{2}{*}{1.4} & 1.25 & 289 & 27.9 & 0.65 & 1.27 & 295 \\
\hline & $\star \star$ & & $\star \star$ & $\star \star$ & $\star \star$ & $\star \star$ \\
\hline
\end{tabular}

Significant at the 1 per cent level.

TABLE 15

EFFECT OF RATE OF APPLICATION OF $\mathrm{Ca}^{45}$ FERTILIZER ON $\mathrm{Ca}^{45}$ CONTENT IN TOMATO SHOOTS

\begin{tabular}{|c|c|c|}
\hline $\mathrm{Ca}^{45}$ applied (ppm.). & 30 & 60 \\
\hline Means (ppm. D.W.). & 17.0 & $33.4 \star \star$ \\
\hline (mg/plant). & 0.4 & 0.7 \\
\hline
\end{tabular}

$\star \star$ Significant at the 1 per cent level.

TABLE 16

EFFECT OF $\mathrm{Ca}^{45}$ FERTILIZER APPLICATION ON THE UPTAKE OF TOTAL CALCIUM IN TOMATO SHOOTS

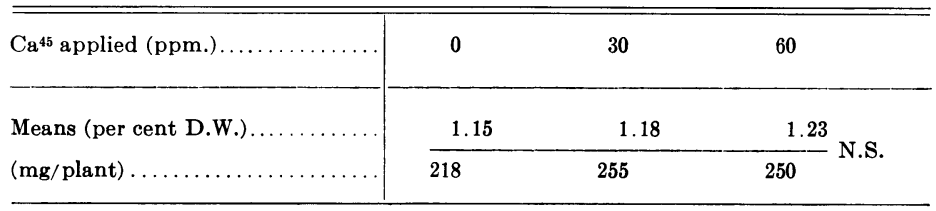

N.S. = not significantly different. 
TABLE 17

EFFECT OF LEVELS OF SOIL BULK DENSITY OF YOLO FINE SANDY LOAM ON PERCENTAGE OF TOTAL CALCIUM IN PLANTS ABSORBED FROM APPLIED Ca ${ }^{45}$ FERTILIZER

\begin{tabular}{l|ccc}
\hline \hline Density $(\mathrm{gm} / \mathrm{cc}) \ldots \ldots \ldots \ldots \ldots \ldots \ldots \ldots$ & 1.7 & 1.1 & 1.4 \\
\hline Means (per cent) $\ldots \ldots \ldots \ldots \ldots \ldots \ldots \ldots$ & 45.6 & $\underline{49.8}$ & 51.7 \\
\hline
\end{tabular}

$\star$ Significant at the 5 per cent level.

TABLE 18

EFFECT OF ROOTSTOCKS ON THE TOTAL CALCIUM AND MAGNESIUM CONTENT OF FOUR TOMATO VARIETIES

\begin{tabular}{|c|c|c|c|c|}
\hline \multirow{3}{*}{ Varieties } & \multicolumn{4}{|c|}{ Means } \\
\hline & \multicolumn{2}{|c|}{ Calcium content } & \multicolumn{2}{|c|}{ Magnesium content } \\
\hline & Per cent D.W. & $\mathrm{mg} /$ plant & Per cent D.W. & $\mathrm{mg} /$ plant \\
\hline $\mathrm{P} / \mathrm{P}$. & 1.11 & 201 & 1.04 & 197 \\
\hline P/SBA. & 1.16 & 218 & 1.11 & 210 \\
\hline SBA/P. & 1.20 & $253 \mid$ & 1.14 & 242 \\
\hline SBA/SBA ..... & 1.28 & 285 & 1.26 & 281 \\
\hline & $\star \star$ & $\star \star$ & $\star \star$ & $\star \star$ \\
\hline
\end{tabular}

$\star \star$ Significant at the 1 per cent level. 
TABLE 19

EFFECT OF ROOTSTOCKS ON PHOSPHORUS CONTENT OF FOUR TOMATO VARIETIES

\begin{tabular}{|c|c|c|c|c|c|}
\hline Varieties $\ldots \ldots \ldots \ldots \ldots \ldots \ldots \ldots \ldots$ & $\mathrm{SBA} / \mathrm{P}$ & SBA/SBA & $\mathbf{P} / \mathbf{P}$ & P/SBA & \\
\hline $\mathbf{m g} /$ plant $) \ldots \ldots \ldots \ldots \ldots \ldots \ldots \ldots \ldots \ldots \ldots \ldots \ldots \ldots$ & 21.4 & 23.5 & 22.7 & 23.4 & \\
\hline
\end{tabular}

Significant at the 5 per cent level.

Significant at the 1 per cent level.

TABLE 20

EFFECT OF LEVELS OF SOIL BULK DENSITY OF YOLO FINE SANDY LOAM AND Ca ${ }^{45}$ FERTILIZER ON PHOSPHORUS CONTENT OF TOMATO SHOOTS

\begin{tabular}{|c|c|c|c|c|c|c|}
\hline \multirow{3}{*}{$\begin{array}{c}\mathrm{Ca}^{45} \\
\text { applied } \\
\text { (ppm.) }\end{array}$} & \multicolumn{6}{|c|}{ Density } \\
\hline & \multicolumn{2}{|c|}{1.1} & \multicolumn{2}{|c|}{1.4} & \multicolumn{2}{|c|}{1.7} \\
\hline & ppm. & $\mathrm{mg} /$ plant & ppm. & $\mathrm{mg} /$ plant & ppm. & $\mathrm{mg} /$ plant \\
\hline 0. & 1,530 & 26.6 & 1,490 & 20.6 & 1,140 & 20.3 \\
\hline 30. & 980 & 20.4 & 1,030 & 23.8 & 1,060 & 26.3 \\
\hline 60. & 920 & 21.0 & 950 & 29.4 & 1,150 & 14.6 \\
\hline
\end{tabular}

Interaction (Ca ${ }^{45} \times$ Density). Significant at the 1 per cent level. 


\section{LITERATURE CITED}

Albert, W. B., and O. Armstrong

1931. Effect of high soil moisture and lack of soil aeration upon fruiting behavior of young cotton plants. Plant Physiol. 6:585-91.

ALDER, H. L., and E. B. RoESSLER

1958. Statistical procedures. Mimeographed. Mathematics Department, University of California, Davis.

Association of OfFicial Agricultural Chemists

1955. Official methods of analysis. Association of Official Agricultural Chemists, Washington, D.C. Ed. 8.

Bertrand, A. R., and H. Kohnke

1957. Subsoil conditions and their effects on oxygen supply and the growth of corn plants. Soil Sci. Soc. Amer. Proc. $21: 135-40$.

Bingham, F. T.

1949. Soil test for phosphate. Calif. Agr. 3(8):11, 14 .

Brown, J. G., G. G. Patten, M. E. Gardner, and R. K. JaCkson

1952. A line-operated Photomultiplier unit for measuring spectral emissions in flame analysis. Amer. Soc. Hort. Sci. Proc. $59: 337-42$.

DANIELSON, R. E., and M. B. RUSSELL

1957. Ion absorption by corn roots as influenced by moisture and aeration. Soil Sci. Soc. Amer. Proc. 21:306.

Dickman, S. R., and R. H. BRaY

1940. Colorimetric determination of phosphate. Ind. Eng. Chem. Anal. Ed. 12:665-68.

ERICKson, L. C.

1946. Growth of tomato roots as influenced by oxygen in nutrient solution. Amer. Jour. Bot. 33:551-61.

Fields, N., P. J. T. King, J. P. Richardson, and L. D. Swindale

1951. Estimation of exchangeable cations in soils with Beckman Flame Spectrophotometer. Soil Sci. 72:219-32.

Flocker, W. J., J. A. Vomocil, and F. D. Howard

1959. Some growth responses of tomatoes to soil compaction. Soil Sci. Soc. Amer. Proc. $23: 188-91$.

HAGAN, R. M.

1950. Soil aeration as a factor in water absorption by the roots of transpiring plants. Plant Physiol. 25:748-62.

HARRINGTON, J. F., and P. A. Minges

1954. Vegetable seed germination. Univ. of Calif. Agr. Ext. Circ. (unnumbered).

Hassid, W. E.

1936. Analysis for total sugars. Ind. Eng. Chem. Anal. Ed. 8:138.

Hopkins, H. T., A. W. SPECHT, and S. B. Hendricks

1950. Growth and nutrient accumulation as controlled by oxygen supply to plant roots. Plant Physiol. 25:193-209.

KAMEN, M. D.

1951. Radioactive tracers in biology. An introduction to tracer methodology. Academic Press, Inc., New York.

LAMBE, T. W.

1951. Soil testing for engineers. John Wiley \& Sons, Inc., New York.

LAWTON, K.

1946. The influence of soil aeration on the growth and absorption of nutrients by corn plants. Soil Sci. Soc. Amer. Proc. $10: 263-68$.

Loenwing, W. F.

1934. Physiological aspects of the effect of continuous soil aeration on plant growth. Plant Physiol. 9:567-83.

Martin, D. C.

1954. The absorption and translocation of radiostrontium by the leaves, fruits, and roots of certain vegetable plants. Ph.D. thesis. Michigan State College. 
Nightingale, G. T., R. M. Addoms, W. R. Robbins, and L. G. SchermerhorN

1931. Effect of calcium deficiency in nitrate absorption and on metabolism in tomato. Plant Physiol. 6:605-30.

RichaRds, L. A.

1954. Diagnosis and improvement of saline and alkali soils. U.S.D.A. Handbook No. 60 : SNEDECOR, G. W.

1956. Statistical methods. Fifth edition. The Iowa State College Press, Ames, Iowa.

TAYLOR, G. A., and G. B. SMITH

1957. Use of plant analysis in the study of blossom-end rot. Amer. Soc. Hort. Sci. Proc. $70: 341-49$.

VeIHMEYer, F. J., and A. H. HeNDRICKson

1948. Soil density and root penetration. Soil Sci. 65:487-93.

Vlamis, J., and A. R. DAVIS

1944. Effects of oxygen tension on certain physiological responses of rice, barley, and tomatoes. Plant Physiol. 19:33-51.

Young, P. A.

1942. Varietal resistance to blossom-end rot in tomatoes. Phytopath. 32(3):214-20. 

The journal Hilgardia is published at irregular intervals, in volumes of about 600 pages. The number of issues per volume varies. Subscriptions are not sold. The periodical is sent as published only to libraries, or to institutions in foreign countries having publications to offer in exchange.

You may obtain a single copy of any issue free, as long as the supply lasts; please request by volume and issue number from:

\author{
Agricultural Publications \\ Room 207 University Hall \\ 2200 University Avenue \\ Berkeley 4, California
}

The limit to nonresidents of California is 10 separate issues on a single order. A list of the issues still available will be sent on request.

In order that the information in our publications may be more intelligible it is sometimes necessary to use trade names of products or equipment rather than complicated descriptive or chemical identifications. In so doing it is unavoidable in some cases that similar products which are on the market under other trade names may not be cited. No endorsement of named products is intended nor is criticism implied of similar products which are not mentioned. 